\title{
Sinergi Pemerintah dan Masyarakat Dalam Pengelolaan Wisata Di Kawasan Hutan Lindung
}

\section{Synergy of Government and Community in Tourism Management in Protected Forest Area}

\author{
Wawan Setiyo Tjahjono ${ }^{1 *}$, Eko Murdiyanto ${ }^{2)}$, Budi Widayanto ${ }^{2)}$ \\ ${ }^{1)}$ Balai Kesatuan Pengelolaan Hutan Yogyakarta \\ 2) Program Studi Magister Agribisnis Fakultas Pertanian Universitas \\ Pembangunan Nasional "Veteran" Yogyakarta \\ ${ }^{1)}$ Jalan Arulobang 13, Baciro, Yogyakarta, Indonesia \\ ${ }^{2)}$ Jalan SWK 104, Condong Catur, Yogyakarta, Indonesia \\ *Email korespondensi : wawan.setiyo.jogja@gmail.com
}

Diterima tanggal : 15 Juni 2021 ; Disetujui tanggal : 30 Juni 2021

\begin{abstract}
This study aims to examine the form of synergy between the government and the community in the collaborative use of protected forests carried out by the Bukit Pengger Tourism Manager. This study uses a qualitative method in collecting data using observations and interviews. The research uses a qualitative method with a case study approach. The results of the study indicate that the synergy between the government and the community in forest management has been implemented through the form of cooperation in the use of protected forests for Bukit Pengger Tourism management activities. The synergy between the government and the community in forest management can be used as a solution for solving problems in forest management by other regions to achieve the main goal of preserving the benefits of forest functions in the context of improving people's welfare.
\end{abstract}

Keywords: cooperation, protected forest, synergy, tourism

\begin{abstract}
ABSTRAK
Penelitian ini bertujuan untuk mengkaji bentuk sinergi pemerintah dan masyarakat dalam kerjasama pemanfaatan hutan lindung yang dilakukan Pengelola Wisata Bukit Pengger. Penelitian ini menggunakan metode kualitatif yang dalam pengumpulan datanya menggunakan observasi dan wawancara. Penelitian menggunakan metode kualitatif dengan pendekatan studi kasus. Hasil penelitian menunjukkan bahwa sinergi antara pemerintah dengan masyarakat di dalam pengelolaan hutan telah terlaksana melalui bentuk kerjasama pemanfaatan hutan lindung untuk kegiatan pengelolaan Wisata Bukit Pengger. Sinergi pemerintah dan masyarakat dalam pengelolaan hutan dapat dijadikan suatu solusi pemecahan kendala permasalahan pengelolaan hutan oleh daerah lain untuk mencapai tujuan utama kelestarian manfaat fungsi hutan dalam rangka peningkatan kesejahteraan masyarakat.
\end{abstract}

Kata Kunci: kerjasama, hutan lindung, sinergi, wisata 


\section{PENDAHULUAN}

Keberlangsungan suatu pelaksanaan pembangunan tidak dapat dilakukan sendiri oleh pemerintah, namun membutuhkan sinergi dengan stakeholders lainya. Namun kendala permasalahan di lapangan seringkali kurangnya keterlibatan stakehoders lainnya begitu juga yang sering terjadi pada pengelolaan hutan. Sinergitas sebagaimana disampaikan Mutis (1992) dalam Parji (2017) adalah perpaduan beberapa inti atau beberapa elemen kalau dipadukan secara bersama memberikan hasil yang lebih baik dan lebih baik manakala mereka berkeja sendirisendiri untuk dapat mencapai tujuan sosial politik tertentu yang semakin lama semakin kompleks, termasuk untuk mewujudkan pengelolaan hutan yang berkeadilan dengan mempertahankan manfaat fungsi lingkungan, sosial dan ekonomi secara seimbang dan berkelanjutan, maka negara perlu berbagi peran, berbagi kekuasaan dan kerjasama dengan kekuatan-kekuatan sosial masyarakat.

Sinergi antara pemerintah dan masyarakat untuk melaksanakan pengelolaan hutan dengan paradigma yang baru menuntut kesungguhan dan komitmen dari semua pihak, tidak terkecuali masyarakat lokal sebagai aktor utamanya. Oleh karena itu pembangunan dimulai dari desa dan pemberdayaan masyarakat desa pinggir dan sekitar hutan hendaknya menjadi prioritas dan dilakukan secara sinergis antara pemerintah dan masyarakat dan terintegrasi. Tantangan bagi kita ialah mempersiapkan penguatan kelembagaan lokal dan kemampuan sumberdaya manusia di tingkat desa.

Dinas Lingkungan Hidup dan Kehutanan (DLHK) DIY dalam hal ini Balai Kesatuan Pengelolaan Hutan (KPH) Yogyakarta melaksanakan kegiatan pengelolaan hutan lindung melibatkan masyarakat sekitar hutan dengan mekanisme kerjasama dengan organisasi masyarakat. Perjanjian Kerjasama antara DLHK DIY dengan Koperasi Noto Wono yang telah diperbarui dengan Perjanjian Kerjasama Nomor : $\frac{119 / 01600}{4 \text { Tahun } 2019}$ Pengelola Wisata Bukit Pengger merupakan salah satu pengelola wisata dari Koperasi Noto Wono yang secara administrasi berkedudukan di Dusun Sendangsari, Desa Terong, Kecamatan Dlingo, Kabupaten Bantul

Pengelolaan Wisata Bukit Pengger yang dilaksanakan sampai tahun keempat pelaksanaan kerjasama sangat minim dari akses kegiatan-kegiatan 
Tjahjono, et.al., Sinergi Pemerintah dan Masyarakat Dalam Pengelolaan Wisata..

pemberdayaan masyarakat dan di sekitar wilayah yang dikelola muncul obyekobyek wisata yang dikembangkan berbagai pihak yang dapat dianggap sebagai pesaing bagi Wisata Bukit Pengger, namun pengelolaan wisata alam yang telah dilakukan dapat dikatakan terbangun dengan baik dan stabil dibandingkan dengan 8 pengelola yang lain sesuai dengan tujuan pengelolaan hutan berkelanjutan. Hal tersebut terlihat pada jumlah masyarakat yang terlibat, banyaknya kegiatankegiatan dari konsumen yang menggunakan lokasi wisata alam, jumlah pengunjung yang banyak terutama saat musim liburan, terbangunnya berbagai fasilitas bagi pengunjung, berkembangnya fasilitas akomodasi dan kuliner di luar kawasan wisata alam, meningkatnya kualitas aksesbilitas menuju lokasi wisata alam.

Penelitian ini bertitik tolak dari sinergi antara pemerintah dan masyarakat dalam pelaksanaan kerjasama dalam Pemanfaatan Hutan Lindung di Bukit Pengger Kecamatan Dlingo, Kabupaten Bantul, Daerah Istimewa Yogyakarta sebagai wisata alam yang keberadaan dan keberlangsungan pengelolaannya dapat berjalan dengan baik sampai dengan saat ini. Berdasarkan latar belakang tersebut penelitian ini bertujuan untuk mengkaji Untuk itu perlu dikaji sinergi pemerintah dan masyarakat dalam pengelolaan hutan lindung dengan mekanisme kerjasama.

\section{METODE PENELITIAN}

Penelitian dilaksanakan di Pengelola Wisata Bukit Pengger, DesaTerong, Kecamatan Dlingo, Kabupaten Bantul pada RPH Mangunan BDH Kulon Progo Bantul Balai KPH Yogyakarta. Tahapan pelaksanaan kegiatan penelitian secara keseluruhan dilakukan kurang lebih selama 6 (enam) bulan, mulai bulan Bulan Januari sampai Juni 2021. Penelitian ini menggunakan penelitiaan kualitatif dengan pendekatan studi kasus. Penelitian kualitatif ini pengumpulan datanya menggunakan observasi dan wawancara. Subyek penelitian yang dipilih untuk diamati adalah Pengelola Wisata Bukit Pengger yaitu Sumar selaku ketua, Galfa selaku Sekretaris, Sugiri selaku bendahara dan Giyarto sebagai anggota Pengelola Wisata Bukit Pengger yang mengetahui awal mula kerjasama pemanfaatan hutan lindung untuk wisata alam dan sampai saat ini masih terlibat secara langsung dalam pengelolaan wisata alam Bukit Pengger. Dalam penelitian ini pengujian keabsahan 
data menggunakan triangulasi sumber dan waktu. Analisis data dalam penelitian ini adalah : data reduction, data display dan conclusion sebagaimana yang dinyatakan oleh Miles and Hubermen (1984) dalam Hariyanti (2015).

\section{HASIL DAN PEMBAHASAN}

Sinergi antara pemerintah dengan masyarakat di dalam pengelolaan hutan telah terlaksana dengan kerjasama pemanfaatan hutan lindung untuk kegiatan pengelolaan wisata antara DLHK DIY dengan Koperasi Noto Wono dimana dalam pengelolaan wisata Blok Pengger diserahkan pelaksanaannya kepada Pengelola Wisata Bukit Pengger. Proses sampai terlaksananya kerjasama pemanfaatan hutan lindung sudah melalui tahapan koordinasi untuk berbagi peran dengan masyarakat sekitar hutan mengelola wisata pada hutan lindung. Pembagian peranan tersebut secara garis besar posisi pemerintah dalam perjanjian kerjasama pemanfaatan hutan lindung adalah sebagai pemilik program dan pengelola kawasan hutan adalah menyediakan lahan kawasan hutan sedangkan Pengelola Wisata Bukit Pengger sebagai pelaksana pengelola wisata dalam kerjasama pemanfaatan hutan. Dalam pembagian peranan tersebut juga dikomunikasikan dan disepakati mengenai hak dan kewajiban antara DLHK DIY dan Pengelola Wisata Bukit Pengger dimana peran, hak dan kewajiban dari masing-masing pihak dituangkan dalam kesepakatan sebagaimana tertuang dalam perjanjian kerjasama dan hingga saat ini dilaksanakan dengan baik.

DLHK DIY dalam hal ini Balai KPH Yogyakarta dengan terbitnya Peraturan Daerah DIY Nomor 7 Tahun 2017 dan Peraturan Gubernur DIY No. 5 Tahun 2018 bersinergi dengan Koperasi Noto Wono untuk secara bersama-sama melaksanakan pemanfaatan hutan lindung untuk kegiatan wisata alam setelah melalui proses koordinasi bagaimana terhadap posisi pemerintah sebagai pihak yang berwenang dan masyarakat yang sangat bergantung kepada hutan untuk pemenuhan kebutuhan hidupnya dalam pengelolaan hutan. Menurut Stephen R. Covey dalam Hayati (2014), sinergi (Synergy) adalah saling mengisi dan melengkapi perbedaan untuk mencapai hasil lebih besar daripada jumlah bagian per bagian. Sinergi merupakan suatu kerjasama yang dapat terwujud ketika kita bisa 
Tjahjono, et.al., Sinergi Pemerintah dan Masyarakat Dalam Pengelolaan Wisata..

mensinkronkan bermacam alternatif keinginan dengan cara komunikasi yang baik antar anggota tim. Dalam bersinergi, kita juga harus berkoordinasi satu sama lain sehingga terwujudnya suatu kegiatan yang efisien. Menurut Moekijat dalam bukunya Koordinasi (Suatu Tinjauan Teoritis) (2002) koordinasi merupakan penyelarasan secara teratur atau penyusunan kembali kegiatan-kegiatan yang saling bergantung dari individu-individu untuk mencapai tujuan bersama.

Sinergi pemerintah dan masyarakat dalam pengelolaan hutan dengan adanya kerjasama DLHK DIY dengan Koperasi Noto Wono dimana pengelolaan wisata diserahkan kepada Pengelola Wisata Bukit Pengger yang telah berlangsung hingga saat ini dapat dijadikan suatu solusi pemecahan kendala permasalahan pengelolaan hutan dengan mempertimbangkan karakteristik masyarakat dan potensi pemanfaatan hutan yang dimiliki oleh daerah lain untuk mencapai tujuan utama kelestarian manfaat fungsi hutan dalam rangka peningkatan kesejahteraan masyarakat.,sebagaimana pendapat Rhodes (2007) dalam Sudirman dkk (2021) kunci dari keberhasilan sinergi dapat dilihat dari 3 hal yaitu: 1) Pemecahan Masalah (Problem Solving) yaitu kemampuan dalam pemecahan masalah yang diantaranya adalah usaha menemukan urutan yang benar dari alternatif jawaban, sehingga menggerakan kita agar lebih dekat dengan tujuan kita juga proses yang dapat membantu seseorang untuk menemukan apa yang mereka inginkan dan bagaimana mencapainya dengan cara yang paling efektif dengan cara merumuskan masalah, menyusun rencana tindakan, dan melaksanakan tindakan yang mengarah pada penyelesaian masalah; 2) Peran Pemerintah (intergovermental games) yaitu bahwa keterpaduan interaksi yang konstruktif antar pemerintah, sektor swasta dan masyarakat; dan 3) Jaringan Komunikasi. Dalam bentuk bagan proses Sinergi Pemerintah dan Masyarakat dalam Pengelolaan Hutan dapat dilihat pada Gambar 1. 


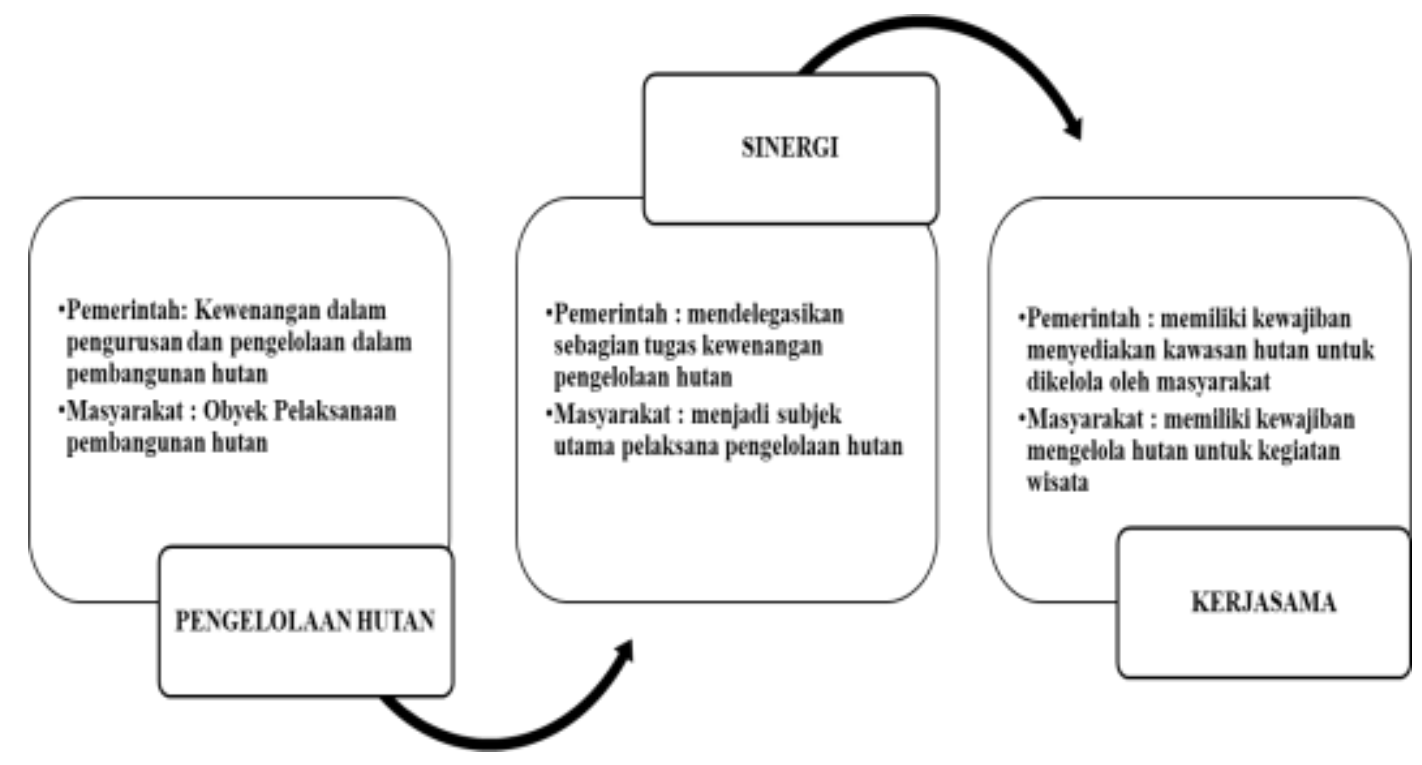

Gambar 1. Proses Sinergi Pemerintah dan Masyarakat dalam Pengelolaan Hutan Sumber : Data primer (2021)

Sinergi pemerintah dan masyarakat dalam pengelolaan hutan dalam bentuk kerjasama memiliki kelebihan yaitu adanya pembagian peranan dan tanggungjawab secara seimbang, pemahaman yang searah dalam pengelolaan hutan, terbentuknya mekanisme koordinasi dan komunikasi yang baik, masyarakat diposisikan sebagai pelaku utama, masyarakat diberi keleluasaan dalam mengelola hutan, fungsi hutan dapat terjaga kelestariaannya, mempertahankan musyawarah dan gotong royong sebagai nilai kearifan budaya lokal masyarakat dan secara ekonomi masyarakat mendapatkan porsi yang lebih besar untuk peningkatan kesejahteraan masyarakat.

Sinergi pemerintah dan masyarakat yang diwujudkan dengan kerjasama pengelolaan wisata alam dapat terlaksana dengan baik ditunjukkan dengan obyek wisata, sarana prasarana dan sarana kuliner Wisata Bukit Pengger tersedia, tertata, terpelihara dan terkelola dengan baik sehingga menjamin kenyamanan pengunjung wisata. Lokasi Wisata Bukit Pengger sudah menjadi titik lokus pengembangan wisata dengan peningkatan dan perkembangan aksesibiltas dan transportasi baik di sekitar lokasi maupun lokasi lain di sekitar dan menuju lokasi wisata alam yang dapat mendongkrak perekonomian masyarakat dengan berkembangnya usaha masyarakat di bidang sarana akomodasi, kuliner, transportasi dan obyek wisata lain. Dari manfaat fungsi hutan dengan terjaganya kelestarian hutan, secara sosial 
Tjahjono, et.al., Sinergi Pemerintah dan Masyarakat Dalam Pengelolaan Wisata..

budaya masyarakat meskipun di tengah perkembangan modernisasi masyarakat dapat mempertahankan musyawarah dan gotong royong sebagai nilai sosial budaya masyarakat lokal. Manfaat ekonomi dengan adanya sinergi pemerintah dan masyarakat sejauh ini meskipun telah dapat mendongkrak ekonomi masyarakat baik Pengelola Wisata Bukit Pengger, masyarakat sekitar hutan maupun masyarakat daerah lainnya juga tidak meninggalkan sisi sosial dari pengelolaan wisata alam dimana hingga saat ini dari Pengelola Wisata Bukit Pengger tetap menyisihkan sebagian keuntungan untuk santunan anak yatim dan orang jompo serta pembanguna sarana pendidikan bagi masyarakat sekitar hutan.

Sinergi pemerintah dan masyarakat dalam pengelolaan hutan sudah dapat terlaksana dengan baik namun dalam suatu sinergi tetap ada kelemahan yang dapat berdampak pada tujuan dari sinergi itu sendiri. Kelemahan sinergi pemerintah dan masyarakat dalam pengelolaan hutan yaitu prosedur yang kompleks sebagaimana dipersyaratkan dalam peraturan yang berlaku dalam pengelolaan hutan, masyarakat dalam mengembangkan inovasi dalam pemenuhan kebutuhan akan sarana prasarana terkendala jenis infrastruktur sesuai peraturan daerah yang berlaku, permodalan yang rendah menyebabkan cukup tingginya biaya operasional dan pemeliharaan sarana prasarana obyek wisata, fasilitas di dalam lokasi kerjasama pengelolaan hutan menjadi hak privat yang dapat menimbulkan permasalahan di masa datang. Kelemahan sinergi pemerintah dan masyarakat dalam pengelolaan hutan tersebut perlu dilakukan upaya-upaya untuk meminimalisir potensi timbulnya masalah yaitu kerjasama harus dibuat dengan seksama dan disepakti terutama untuk mengantisipasi dinamika perubahan peraturan pengelolaan hutan ke depannya, perencanaan untuk jangka pendek, menengah dan panjang yang baik, melakukan penilaian manajemen risikosecara sebelum melaksanakan sinergi pemerintah dan masyarakat dalam pengelolaan hutan agar tidak terjadi kerugian dari pihak pemerintah maupun masyarakat yang dapat menggagalkan tujuan sinergi pemerintah dan masyarakat dalam pengelolaan hutan yaitu kelestarian hutan terjaga dan peningkatan kesejahteraan masyarakat.

Kerjasama pengelolaan Wisata Bukit Pengger merupakan suatu bentuk pemanfaatan hutan lindung selain dari hasil hutan bukan kayu yaitu Jasa lingkungan 
dan Wisata Alam dengan salah satu bentuk pengelolaannya dengan mekanisme kerjasama. Hal yang mendasarinya adalah Peraturan Daerah DIY Nomor 7 Tahun 2015 tentang Pengelolaan Hutan Produksi dan Hutan Lindung DIY yang dalam pelaksanaanya diterbitkan Peraturan Gubernur DIY Nomor 84 Tahun 2016 tentang Kerjasama Pemanfaatan Hutan Lindung yang telah diubah dan diperbaharui dengan Peraturan Gubernur DIY Nomor 5 tahun 2018 tentang Kerjasama Pemanfaatan Hutan Produksi, Hutan Lindung dan Perizinan Tahura.

Pengelolaan hutan lindung untuk wisata alam sebagai bentuk kerjasama antara Koperasi Noto Wono dengan DLHK DIY sebagaimana yang telah dilaksanakan mulai tahun 2017 hingga saat ini. Dalam hal pelaksanaan kerjasama untuk mengelola Bukit Pengger Koperasi Noto Wono menyerahkan pelaksanaan pengelolaan wisata alam dalam kerjasama pemanfaatan hutan lindung tersebut kepada Pengelola Wisata Bukit Pengger. Menurut pendapat Amirullah (2015) dalam Rustam (2018) kerjasama dapat juga diartikan sebagai bekerja luar biasa atau mewajibkan diri sendiri untuk berbuat lebih daripada yang menjadi kewajiban sendiri karena dengan cara itu berarti juga ikut menolong atau memberi keuntungan bagi kepentingan bersama.

Kerjasama menurut pendapat Prasojo (2015) memposisikan kedudukan pemerintah yang awalnya sebagai pelaku utama dalam pembangunan mulai dari tahap perencanaan, pelaksanaan sampai dengan evaluasi, berubah menjadi pola penyelenggaraan pelayanan dan fungsi pemerintah yang tidak lagi didominasi oleh satu pihak saja (pemerintah). Konsep ini menekankan pemerintah sebagai pengendali sumber-sumber yang ada di masyarakat dan tidak melakukan pembangunan sendiri. Selain itu pemerintah juga harus mampu memberdayakan masyarakat dalam pemberian pelayanan, sebagaimana telah dilaksanakan dalam pengelolaan hutan lindung untuk wisata alam sebagai bentuk kerjasama antara Koperasi Noto Wono dengan DLHK DIY sebagaimana yang telah dilaksanakan mulai tahun 2017 hingga saat ini. Dalam hal pelaksanaan kerjasama untuk mengelola wisata alam Bukit Pengger yang terletak di blok Terong RPH Mangunan, BDH Kulon Progo - Bantul seluas 3,80 hektar Koperasi Noto Wono menyerahkan pelaksanaan pemanfaatan hutan lindung kepada Pengelola Wisata 
Tjahjono, et.al., Sinergi Pemerintah dan Masyarakat Dalam Pengelolaan Wisata..

Bukit Pengger yang berkedudukan di dusun Sendangsari, Kalurahan Terong, Kapanewon Dlingo, Kabupaten Bantul dengan tujuan optimalisasi usaha wisata alam untuk memperoleh manfaat ekologi, sosial dan ekonomi baik bagi masyarakat maupun pemerintah.

Pengelolaan hutan dalam hal ini pemanfaatan hutan lindung dengan mekanisme kerjasama ditujukan untuk meningkatkan kesejahteraan masyarakat sekitar hutan dengan tetap menjaga kelestarian fungsi hutan secara berkelanjutan dimana masyarakat sekitar hutan terlibat langsung secara aktif dalam kerjasama pemanfaatan hutan lindung. Pengelolaan hutan dengan kerjasama sebagai wujud dari sinergi antara pemerintah dan masyarakat merupakan paradigma baru untuk menjadikan semua stakeholder dalam pembangunan mempunyai peran yang seimbang guna mencapai tujuan utama pembanguan yakni kesejahteraan masyarakat. Karena yang dimaksud kesejahteraan bukanlah hanya sekedar terpenuhinya kebutuhan pokok yang terdiri dari pangan, sandang, dan perumahan atau pemukiman, namun lebih dari itu. Pendapat Goulet yang dikutip Theresia (2014) mengemukakan bahwa terdapat tiga nilai yang terkandung dalam kesejahteraan, yakni: a) tercapainya swasembada (kemampuan masyarakat memenuhi kebutuhan dasar seperti sandang, pangan, pemukiman, kesehatan, pendidikan dasar, keamanan, dan sebagainya; b) peningkatan harga diri (berkembangnya rasa percaya diri untuk hidup mandiri dan tidak tergantung pada pihak lain); c) diperolehnya kebebasan untuk mengembangkan usaha memperbaiki mutu hidup tanpa adanya tekanan dari pihak lain. Atau dengan kata lain dengan kerjasama pemanfaatan hutan lindung adalah upaya pemerintah dalam pemberdayaan masyarakat sekitar hutan melalui pemanfaatan hutan lindung dengan pengembangan potensi yang ada pada hutan lindung dan masyarakat sekitar hutan lindung.

\section{SIMPULAN}

Sinergi antara pemerintah dengan masyarakat di dalam pengelolaan hutan dengan keseimbangan peranan antara pemerintah dan masyarakat telah diwujudkan dalam bentuk kerjasama pemanfaatan hutan lindung untuk kegiatan pengelolaan 
wisata antara DLHK DIY dengan Koperasi Noto Wono dimana dalam pengelolaan wisata blok Pengger diserahkan pelaksanaannya kepada Pengelola Wisata Bukit Pengger dengan tujuan tercapainya nilai kesejahteraan yaitu tercapainya swasembada, peningkatan harga diri melalui berkembangnya rasa percaya diri untuk hidup mandiri dan tidak tergantung pada pihak lain dan kebebasan untuk mengembangkan usaha memperbaiki mutu hidup tanpa adanya tekanan dari pihak lain.

Perlu dilakukan upaya-upaya untuk meminimalisir potensi timbulnya masalah yaitu kerjasama harus dibuat dengan seksama dan disepakti terutama untuk mengantisipasi dinamika perubahan peraturan pengelolaan hutan ke depannya, perencanaan untuk jangka pendek, menengah dan panjang yang baik, melakukan penilaian manajemen risikosecara sebelum melaksanakan sinergi pemerintah dan masyarakat dalam pengelolaan hutan agar tidak terjadi kerugian dari pihak pemerintah maupun masyarakat yang dapat menggagalkan tujuan sinergi pemerintah dan masyarakat dalam pengelolaan hutan yaitu kelestarian hutan terjaga dan peningkatan kesejahteraan masyarakat.

\section{DAFTAR PUSTAKA}

Hariyanti, M. (2015, Juni 10). Analisis Data Kualitatif Miles dan Hubermen. Diperoleh dari https://www.kompasiana.com/meykurniawan/556c450057937332048b456 c/analisis-data-kualitatif-miles-dan-hubermen

Hayati,N. (2014). Sinergi Lembaga-Lembaga Pemerintahan/Bumn Dalam Penyaluran Bantuan Program Keluarga Harapan (Pkh) Di Kota Samarinda. eJournal Ilmu Pemerintahan, 2 (4), 3482-3496

Milles, Matthew B. dan Huberman, Michael. (1984). Qualitative Data Analysis. London: Sage Publication

Moekijat. (2002). Koordinasi (Suatu Tinjauan Teoritis). Bandung. CV. Mandar Maju.

Parji. (2017). Studi Tentang Sinergitas Antar Stakeholder Dalam Implementasi Kebijakan Asi Eksklusif Di Kawasan Kecamatan Rungkut Berdasar Peraturan Pemerintah Nomor 33 Tahun 2012 Tentang Pemberian Air Susu Ibu Eksklusif. Kebijakan dan Manajemen Publik, 5, (1), 1-13 
Tjahjono, et.al., Sinergi Pemerintah dan Masyarakat Dalam Pengelolaan Wisata..

Prasojo,R.A. (2015). Peran Pemerintah-Masyarakat Dalam Pembangunan Desa (Studi Di Desa Sedatigede Kecamatan Sedati Kabupaten Sidoarjo). (Skripsi). Fakultas Ilmu Sosial Dan Ilmu Politik. Universitas Muhammadiyah Sidoarjo. Sidoarjo

Rustam,R. (2018). Kerjasama Pemerintah Dan Masyarakat Dalam Penanggulangan Bencana Di Kabupaten Luwu Utara. (Skripsi). Universitas Muhammadiyah Makassar. Makassar

Sudirman, F, Alyas, Abdi. (2021). Sinergi Pemerintah Dan Masyarakat Dalam Penanggulangan Persampahan Di Pasar Sentral Kabupaten Enrekang. Journal Unismuh, 2, (1), 308-322

Theresia. A, Andini. KS, Nugraha. P.G.P, Mardikanto. T . (2014). Pembangunan Berbasis Masyarakat: Acuan Bagi Praktisi, Akademis, dan Pemerhati Pengembangan Masyarakat. Bandung: Penerbit Alfabeta. 